\title{
Israel's Prophets and their Confrontation with the Canaanite Religion
}

\author{
By ARVID S. KAPELRUD
}

The confrontation between Israelites and Canaanites is presented in the Old Testament historical books as a violent encounter, a battle which was waged between tribes who invaded Canaan from Egypt and the people who already lived in the land and neighbouring territories. The narrators who composed the Deuteronomistic historical work (Deuteronomy, Joshua, Judges, I and II Samuel, I and II Kings) have, with background in the situation in which they themselves lived, described it such that Moses gave the order for a complete extermination of other people and tribes in those regions where they settled down (Deut. $7:$ I ff.). The intention was that the tribes should not be tempted to take up the inhabitants' religion, thereby disrupting the domestic, harmonious unity among the Israelites and starting an internal disintegration.

This is clearly and undoubtedly a description which is made very long after the actual events, and it obviously falls short of a correct representation of what happened. As early as the book of Joshua, which belongs to the same historical work, do we find indications to this effect. This book gives in very compressed form a description of the Israelites' conquest of Canaan, concluded by Joshua's renewal of the covenant at Shechem (Josh. 24). As especially the German scholars Albrecht Alt and Martin Noth have shown, the book of Joshua has shortened historical incidents which occurred during several centuries, to events which took place without intermission over only a few years. The archaeological work which has been done in Palestine in recent years, not the least by Kathleen Kenyon and J. B. Pritchard, has confirmed at many points that this construction is correct. There were many hard battles between Israelites and Canaanite communities, but a slow and more peaceful infiltration took place as well. The latter could not so easily have played a part in historical presentations, but 
culturally and religiously it probably was more meaningful and significant than the martial conquests. Unfortunately, it is also much more difficult to demonstrate, especially since our written sources record so little about it.

The Old Testament itself (O.T.) has, to be sure, preserved the remembrance of a more peaceful infiltration of the land. It is this which characterizes the traditions about the patriarchs, who came from Aramaic-Amorittic tribes in northern Mesopotamia, wandered southward and settled down in the middle and southern parts of Canaan-Abraham, Isaac, and Jacob. The patriarchs are described as peaceful, nomadic herdsmen who roamed about and stayed only where there were good grazing land. They represent a group of immigrants who came from the north and certainly had their own culture, though distinctly a culture with simple lines, as might be expected from a people who had no permanent settlement. After a while they settled down and became tillers of the soil; but this meant also that they had to acquire a new culture, the farmer's, such as that which was represented among the Canaanites and other groups who had attached themselves to the land. It was not just a question of acquiring a new technique; it was a complete alteration of existence-from the nomad's wandering life to the farmer's more stable, but ever more risky, existence. The stories in Genesis reflect a little of the tension which lay in this great transposition.

The Old Testament narrators have, as mentioned, preserved the remembrance that Hebrews of different origins at separate times have penetrated into Canaan and settled there. Through a genealogical connection they have tied together, in a simple and ingenious way, the different groups of immigrants and thereby been able to give them common traditions. The latter were not yet completed by David's time, and it was an essential part of David's accomplishments that he tried to connect northern and southern tribes and at the same time unite them with the Canaanites and give them all a new center at the old Jebusite city of Jerusalem.

With David there appears to have taken place consciously that which already had been in process for several hundred years - the amalgamation of Canaanite and Israelite: the continued development, in fact, demanded that this be accomplished if David's new kingdom was not to be broken up into its separate members. The Israelite tribes had, with the passage of time, appropriated the farmer's culture and with it also much of its 
religion. They acquired the new culture of cities and commerce, and they learned to extract and forge iron. They learned navigation from the Phoenicians, and they traveled out on trading expeditions to the neighbouring lands.

At the same time as this expansion was occurring, the two kings David and Solomon expanded the administrative apparatus in Israel. Just as important was the securing of the spiritual unity, which had taken its center in Jerusalem and in the cult which was developed there. Here it was that David had to take into consideration the Canaanite part of the population. He could not simply establish a Yahweh-cult which took no notice of the Canaanites' El- and Ba'al-religion. As far as one can judge from several features in David's policy concerning this matter, especially from the programmatic names he gave his sons, he seerns to have tried to unite the dissimilar religious forms, not the least through an identification of Yahweh and the Canaanites' highest god El, in Jerusalem called Salem or El Elyon. This identification was no new feature from David's side, and it ended as a success. In fact, the characteristic traits from these two gods became united into the picture which eventually was accepted.

More difficult, however, was the situation with Ba'al. This popular god of rain and fertility was closely connected to agriculture-so closely, in fact, that it was not easy to separate him from the complex of actions and ideas which were bound to the yearly progression in field and meadow and among the animals. That which drove agriculture also drove the Ba'al-cult. The earth's life and fertility were bound to Ba'al. If he should disappear completely from the scene, another had to come in his place. It had to be one who had the same power as Ba'al, that of giving rain and fertility.

We know little about how Israelite tribes first reacted to Ba'al. Probably there was no reaction at all; he slipped naturally into their conscious life together with all else new which was attached to agriculture. The later narrators can express that Moses had dissociated himself from the Ba'al-cult already before the tribes reached Canaan (Num. 25), but at the same time the narrator also gives a glimse of how natural this cult could be for the Israelites. The whole story in Num. 25 pictures the later reaction, but it also emphasizes unconsciously that the fertility-cult was a close possibility.

It was, in fact, so viable an option that in one way or another it had to be 
identified with Yahweh if he was not to disappear out of the picture. For the domineering Israelite-Judaic groups it was a necessity to find the means for the solution of this problem. The Yahweh-Ba'al identification appeared to cause difficulties; but the final solution nevertheless went half-way along this direction, as it indeed seems, with a strong polemic against Ba'al.

What is clearly indicated in the sources is that Yahweh was set up as the real God of fertility. It was he who had created all; it was he who provided the rain, who opened the sluices of heaven and caused brooks and springs to flow forth. He provided for the crops; he let the produce of the field thrive. Several of the Psalms give witness to this (Ps. 74, 148).

This was an essential point, decisive for the fate of the religion of Yahweh in Canaan. Israelite traditions have preserved the remembrance of this significant shifting in the points of view and the ceremonies of the cult, and they have been transmitted to later generations in the dramatic form which the traditions have received in I Kings 18 , the contest between the prophet Elijah and the prophets of Ba'al on Mount Carmel in the days of King Ahab. The Deuteronomistic writers certainly build here upon old sources which have preserved a part of the nucleus itself in the account, that around which it really pivoted but which each generation has clearly handed down in ever more fantastic and exciting form. The contrast is sharply drawnthe one, lonely prophet of Yahweh, Elijah, against the four hundred fifty prophets of Ba'al, supported by the king and queen.

The comparison of Yahweh with Ba'al is accomplished by means of a contest on a rather simple, decisive plain. It concerned the question of which of the two was the genuine rain- and fertility-god. There is nothing else involved in the narrative, and the test proceeds exclusively on this point. Its aim was to bring an end to the protracted drought which long had ravaged the land (I Kings r 7 : 1 ff.). Elijah and the prophets of Ba'al met on Carmel, an ancient cultic place, for the decisive battle. In vain the Ba'al-prophets offered their sacrifice; in vain they called to their god; in vain they danced their cultic dance. No reaction was visible, and Elijah mocked them. In order to demonstrate Yahweh's effectivity as rain- and storm-god, he made the people pour great quantities of water over the sacrifice and, in addition, fill a trench which was dug around the altar. After Elijah had offered his prayer at the time of the evening offering, Yahweh entered the scene. His 
bolt of lightning set the wood and the sacrificed animal on fire and dried up the water in the trench. Yahweh was the real thunder- and storm-god. There soon also appeared dark clouds over the sea in the west, and the rain poured down. Yahweh had shown that he was the one who gave rain and fruitfulness; it was not Ba'al's work. Here is the nucleus in the old narrative, the essential point which has been so greatly dramatized. It was a point of intersection in the encounter between the Ba'al-cult and the religion of Yahweh.

It could be, nevertheless, that the adjustment would have succeeded without any insurmountable problems if it were not for something new which occurred. The question arises as to whether there were no new factors which led to the sharp reaction from several prophets in the time of the monarchy. It could, of course, have been a slowly awakening reaction to phenomena which after some time had assumed sharper contrasts, but it seems to be that new elements have released the sharp opposition which the prophets' speeches and actions indicate. The completely accurate picture of this cannot be derived from the historical writings because the writers of the Deuteronomistic history and the theologically-oriented authors of the Priestly writings have presented the history according to their own perspectives. Among these authors and interpretors of history the work of the prophets had already set its mark and impressed their viewpoints also on this older story.

How the process of amalgamation between the Yahweh-cult and the $\mathrm{Ca}-$ naanite fertility-cult proceeded in detail is not open for easy investigation, but it can with great probability be said that it developed much more peacefully and extensively than the presentations in the O.T.'s historical books seem to indicate. At any rate, it is certain that there also have been frictions and resistances at different points. Even David's policies point to this. If it had not been for opposing factors to be united, he would indeed not have taken the trouble with it. David operated on a line which already had proceeded long down the road to success, and he seems to have given much attention to it.

But after his time the circumstances were altered. King Solomon perhaps intended to carry this line further, but he lacked the internal balance in his politics which his father had had. Foreign elements and irritating factors 
of significant weight began to stand strongly in the foreground. It is not so strange that that which was about to occur was a confrontation with the internationally-oriented culture which asserted itself at the kingly courts, among scribes and scholars, and among the many who were connected to or directly took part in the commerce which through the Phoenicians stretched out over the entire Near-Orient. King Solomon's connection with this world and this milieu was preserved by the tradition which pictured him as the wise man who had all the insight which impressed his contemporaries (I Kings 4:29-34). His co-operation with King Hiram of Tyre and the Phoenicians is also given prominence (I Kings $5: \mathrm{Iff}$; 9:26-28; I0:22 f.).

The dividing of the kingdom in 922 disrupted much of what David and Solomon had done, but in both kingdoms an attempt was made to build further upon that which already existed, even if it could now be only a torso. While the kingdom of Judah in the south retained the new central sanctuary in Jerusalem, the rebel Jeroboam tried to utilize ancient cultcenters farther north. I Kings I 2 relates that he set up images of bulls in Bethel and Dan in order to assemble people there. The narrator has the king say to the people: "Here is your God, Israel, who led you out of Egypt" (I Kings 12:21). The narrator can here have preserved an historical remembrance which for him appeared disdainful, but which from the king's side was certainly not intended as such. Both $\mathrm{El}$ and Ba'al were represented in the form of bulls; and if the king wanted to continue David's line of identification, his words are very understandable. In later times Jeroboam I was regarded as the main idol-worshipper (I Kings $13: 33 \mathrm{f}$.); but in his own time there does not seem to have been such strong reactions, something which well explains the characteristic prophetic legend in I Kings I3, about the prophet from Judah who attacked the king with strong words as he stood by the altar, but later abandoned his task and met death. In and of itself, it is not inconceivable that a prophet from Judah could have denounced Jeroboam I, such as Amos $15^{\circ}$ years later did with Jeroboam II; but the narrative in I Kings $\mathrm{I} 3$ has a legendary stamp which is altogether too distinct. It is clear that in Israel there existed no historical remembrances that prophets had anything to say about Jeroboam's religious policies in his own time.

We stand on somewhat more solid ground when we come to King Ahab's 
time $(869-850$ B.C.). Here the details which are interpreted concerning prophets like Elijah (I Kings 18 f.) and Micaiah ben Imlah (I Kings 22) are open for discussion, but it is obvious that in Ahab's time there was about to appear a sharp reaction against the kings' policies on religion, which, among other things, resulted in Jehu's revolution against the dynasty of Omri.

By this time the tension between Yahweh and Ba'al had become manifest. The distinct form for the fertility-cult, which from old times had been connected to $\mathrm{Ba}$ 'al, seems to have been difficult for the adherents of Yahweh to accept. The difference which was present was also brought more sharply into relief through the Ba'al-cult which had been encouraged and supported from royal quarters, and not the least from the queens' side, all the way from King Solomon's time forward. Ahab's Tyrian queen Jezebel had quite particularly supported the Ba'al-cult in Israel and thereby provoked to the fore a sharper attitude and a clearer reaction on the part of the Yahweh adherents. With this the relationship between the Yahweh-cult and the Ba'alcult became fixed and was stamped by the strong opposition which the prophets so often took occasion to express.

This expression is especially sharp with the prophet Hosea, who worked in the Northern Kingdom after ca. $75^{\circ}$ B.C. He is the first of the prophets who used the designation "prostitute" for the connection to Ba'al and who personified Israel as the faithless wife. He represents a direct continuation of the line which began with Elijah. The prophet's words in $2: 8 \mathrm{ff}$. aim directly at this: "For she did not know that I gave her grain and wine and oil and added to her silver and gold, which they used for $\mathrm{Ba}$ 'al ... And I will destroy her vines and her fig trees. Of these she has said: 'This is my hire, which my lovers have given me.' ... And I will punish her for the days with the Ba'als when she burned incense to them and adorned herself with her earrings and jewelry and went after her lovers and forgot me, says Yahweh."

These prophetic words are programmatic and show clearly what they concern. 'The Ba'al-cult is regarded as foreign, deviating from a true Yahwehcult; the two are no longer reckoned as being capable of union. The prophet's mode of expression gives the impression that the Ba'al-cult was old and established among the Israelites; it implies direct continuation of the 
Canaanite cult. But the sharp, uncompromising reaction to an old and well-known phenomenon suggests that something new must have entered the picture. It is certainly the Phoenician Ba'al-Melkart worship which has worked as a catalyst and opened the Israelites' eyes to the difference between Yahweh and Ba'al.

In addition there comes also another factor. Hosea uses the disqualifying designation "prostitute" (zenut) in reference to the relationship with Ba'al, a designation which does not find its origin only in the religious sphere, but just as much in the moralistic. Here is an ethical factor which later prophets as well did not fail to underscore. It is the entire fertility-cult which is here characterized and discriminated as zenut, seen from the perspective of faith in Yahweh. The breach between Yahweh and Ba'al was complete and unalterable.

How ethical viewpoints had come strongly into the picture can also be seen in Hosea's earlier contemporary, the prophet Amos. The socialethical outlook was domineering here. Israel had forsaken Yahweh by means of breaking the solidarity in the covenantal community; those who had the power in the society had misused it, and a strong class-division was the result. If this was not corrected, Yahweh would bring down his inexorable justice upon the people.

Here Yahweh's will is identified with the right and the moral as in the old, simple, agricultural and semi-nomadic society. It is the new urban and commercial morality, such as it was taken over from Phoenician circles, against which the prophet reacted. This was not the will of Yahweh; it was a breach with something of that which was the nucleus in the old community.

For Amos it was not a battle against Canaanite conceptions and customs. He fought against something new, characterized by the international commercial culture of the times, imported from Phoenicia, but willfully adopted by Israelites. The old customs and habits which Amos wanted to revive were, however, not simply early-Yahwistic; they represented a combination of Yahwistic and Canaanite. Both with the farmer and the nomad could be found the community-solidarity for which Amos sought, less perhaps among the nomads than among the farmers.

The usual, popular interpretation of Israel's prophets is that they stood 
as watchmen over the pure Yahweh-faith and sharply repudiated all that was Canaanite. It must at any rate be said that the prophets' reaction took hold at a late point in time, after the welding together of Israelite and Canaanite elements had proceeded very far.

If we look at the first great prophets of doom, we should certainly expect that with them the reaction against the Canaanite elements must have been very strong. This has also been commonly assumed, but it does not entirely agree with the actual circumstances. It was the new impulses from Phoenicia, supported by courtly circles and widely spread through the international commerce and navigation, which gave rise to counter-currents and led to a sharp reaction, such as is expressed among the prophets of doom. 